\title{
EPHB4 wt Allele
}

National Cancer Institute

\section{Source}

National Cancer Institute. EPHB4 wt Allele. NCI Thesaurus. Code C113831.

Human EPHB4 wild-type allele is located in the vicinity of $7 q 22$ and is approximately 25

$\mathrm{kb}$ in length. This allele, which encodes ephrin type-B receptor 4 protein, is involved in ligand-dependent signaling pathways. 